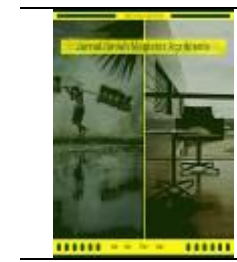

\title{
Kajian Ketersediaan Pupuk Bersubsidi dan Harga Pupuk Terhadap Produksi Padi Sawah di Kabupaten Batubara
}

\section{Study of Subsidized Fertilizer Availability and Price of Fertilizer on Paddy Production in Batubara District}

\author{
Yayan Noviandi Ananda Tanjung1), Yusniar Lubis²), Syaifuddin Lubis ${ }^{3)}$ \\ 1) Magister Agribisnis, Pascasarjana, Universitas Medan Area, Indonesia \\ 2) Dosen Magister Agribisnis, Pascasarjana, Universitas Medan Area, Indonesia \\ 3) Fakultas Ekonomi, Universitas Prima Indonesia, Indonesia
}

\begin{abstract}
Abstrak
Produksi padi sawah sangat perlu ditingkatkan karena padi merupakan tanaman makanan pokok masyarakat. Kabupaten Batu Bara merupakan salah satu lumbung padi di Sumatera Utara sehingga sangat penting melakukan berbagai upaya peningkatan produksi padi. Diantara faktor yang dapat meningkatkan produksi padi sawah adalah ketersediaan pupuk bersubsidi dan harga pupuk bersubsidi sesuai Harga Eceran Tertinggi (HET). Tujuan utama penelitian ini adalah untuk mengetahui pengaruh ketersediaan pupuk bersubsidi dan harga pupuk bersubsidi sesuai Harga Eceran Tertinggi (HET) terhadap produksi padi sawah di Kabupaten Batu Bara. Metode penelitian yang dilakukan adalah metode kuantitatif dengan responden sebanyak 100 orang petani padi sawah di Kabupaten Batu Bara. Berdasarkan hasil penelitian diketahui bahwa ketersediaan dan harga pupuk bersubsidi secara simultan dan parsial berpengaruh signifikan terhadap produksi padi sawah di Kabupaten Batubara. Pengaruh variasi ketersedian dan harga pupuk bersubsidi terhadap produksi padi adalah sebesar 66,7 \%. Ketersediaan pupuk bersubsidi secara rata-rata di Kabupaten Batubara adalah sebesar 94,56\%. Secara parsial, ketersediaan pupuk bersubsidi berpengaruh negatif terhadap produksi padi sawah di Kabupaten Batubara. Kondisi disebabkan sebagian petani ada yang memperoleh pupuk bersubsidi lebih dari yang dibutuhkan. Harga pupuk bersubsidi secara parsial berpengaruh positif terhadap produksi padi sawah, artinya bahwa harga pupuk bersubsidi masih dalam tingkat kemampuan petani.
\end{abstract}

Kata Kunci : produksi padi, pupuk, subsidi.

\begin{abstract}
Paddy rice production needs to be improved because rice is the staple food of the community. Batu Bara Regency is one of the rice granaries in North Sumatra so it is very important to make various efforts to increase rice production. Among the factors that can increase rice production are the availability of subsidized fertilizer and the price of subsidized fertilizer according to the Highest Retail Price (HET). The main purpose of this study is to determine the effect of subsidized fertilizer availability and the price of subsidized fertilizer in accordance with the Highest Retail Price (HET) on paddy rice production in Batu Bara Regency. The research method is quantitative method with 100 respondents of rice farmers in Batu Bara Regency. Based on the results of the research, it is known that the availability and price of subsidized fertilizer simultaneously and partially have a significantly effect on the production of lowland rice in the Batubara Regency. The effect of variation in availability and price of subsidized fertilizer on rice production is $66.7 \%$.. The availability of subsidized fertilizer at Batubara Regency is $94.56 \%$. Partially, the availability of subsidized fertilizer has a negative effect on the production of lowland rice in the Batubara Regency. The condition is caused by some farmers who get subsidized fertilizer more than needed. The price of subsidized fertilizer partially has a positive effect on paddy rice production, meaning that the price of subsidized fertilizer is still in the level of farmers' ability Keywords: rice production, fertilizer, subsidy
\end{abstract}

How to Cite: Tanjung, Y.N.A., Y. Lubis \& S. Lubis. (2020). Kajian Ketersediaan Pupuk Bersubsidi dan Harga Pupuk Terhadap Produksi Padi Sawah di Kabupaten Batubara. Jurnal Ilmiah Magister Agribisnis, 2(2) 2020: 208-216,

*E-mail: Yusniar@uma.ac.id ISSN 2550-1305 (Online)

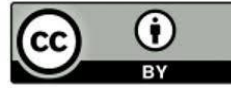




\section{PENDAHULUAN}

Sektor pertanian merupakan sektor yang memiliki peran strategis dalam pembangunan nasional. Pembangunan nasional pada dasarnya merupakan suatu proses perubahan struktural dalam bidang sosial dan ekonomi. Proses perubahan tersebut haruslah merupakan suatu proses yang dinamis dan menuju yang lebih baik dari suatu tahap ke tahap berikutnya yang berorientasi kepada bagaimana memenuhi kebutuhan pokok (basic good). Salah satu kebutuhan pokok itu adalah pangan, dimana pangan merupakan salah satu kebutuhan dasar manusia yang paling utama. Pada dasarnya, kedaulatan pangan (food sovereignty) merupakan kebijakan utama pembangunan pertanian yang hendak diwujudkan Kabinet Kerja Pemerintah Republik Indonesia 20142019 (Wahyu dan Setiawan, 2017: 10).

Pertanian merupakan aspek penting dalam mendukung keberlangsungan hidup suatu negara. Selain itu, pertanian sebagai aspek pendukung ketersedian pangan di suatu negara. Salah satu permasalahan yang dihadapi dalam mendukung produksi pangan adalah ketersediaan pupuk pada saat musim tanam. Sering terjadi kelangkaan pupuk di pasar sehingga berdampak pada rendahnya produktivitas tanaman pangan seperti padi dan jagung yang dihasilkan. Jika kondisi tersebut dibiarkan berlanjut, akan menyebabkan sektor pertanian tidak menarik bagi petani di Indonesaia dengan dampak negatif terhadap ketahanan pangan nasional.

Oleh karena itu, terdapat berbagai kebijakan pemerintah yang mendukung produksi sektor pertanian. Salah satu kebijakan ini adalah kebijakan subsidi pupuk. Hal ini sejalan dengan apa yang dikemukakan Menteri Pertahian RI bahwa: Kedaulatan pangan tidak akan terwujud tanpa jaminan ketersediaan lahan pertanian yang berkelanjutan, tanpa jaminan fasilitas irigasi dan pasokan air yang memadai, tanpa jaminan pasokan pupuk yang sesuai dengan kebutuhan dan karakteristik lokasi, tanpa jaminan ketersediaan benis yang berkualitas dan sesuai dengan spesifikasi wilayah pengembangan, tanpa jaminan ijin investasi, tanpa jaminan daya dukung lingkungan, tanpa jaminan dan dukungan ilmu pengetahuan dan teknologi, tanpa dukungan daerah dan sebagainya (Wahyu dan Setiawan, 2017: 10).

Pupuk merupakan masukan penting untuk produksi pertanian. Dengan semakin populernya pertanian modern, konsumsi pupuk di negara-negara berkembang terus meningkat. Perubahan terhadap kebijakan subsidi pupuk di Indonesia telah sering terjadi dan diamati, dalam upaya memenuhi permintaan petani untuk memperoleh pupuk yang berkualitas. Perubahan Kebijakan subsidi pupuk terhadap perdagangan dan distribusi pupuk awalnya secara keseluruhan berdampak positif terhadap pasokan pupuk. Namun demikian, deregulasi kebijakan subsidi pupuk sebagian besar tidak bisa menjamin terhadap kualitas pupuk dalam jumlah yang dibutuhkan dan waktu yang tepat (Nizar dan Aryanto, 2016: 34).

Kebijakan subsidi pupuk merupakan salah satu kebijakan fiskal yang bertujuan untuk mendukung sektor pertanian, khususnya tanaman pangan dengan memberikan subsidi input berupa penetapan Harga Eceran Tertinggi (HET) pupuk. Pupuk merupakan masukan penting untuk produksi pertanian. Dengan semakin populernya pertanian modern, konsumsi pupuk di negara-negara berkembang terus meningkat. Perubahan terhadap kebijakan subsidi pupuk di Indonesia dilakukan dalam upaya memenuhi kebutuhan petani untuk melakukan penanaman padi sehingga mampu menghasilkan produksi padi secara maksimal.

Berdasarkan data luas lahan dan persentase produksi padi di tahun 2016 ada hal yang tampaknya kurang realistis dimana luas areal sawah tidak diimbangi dengan hasil produksi sebagai contoh di Kecamatan Air Putih dengan luas areal 4.294 hektar hanya 
mampu memproduksi padi sebanyak 48.474 ton dari total produksi di Kabupaten Batubara sedangkan pada Kecamatan Lima Puluh dengan areal sawah 3.694 hektar mampu memproduksi padi sebanyak 53.499 ton dari total produksi padi di Kabupaten Batubara.

Untuk mengetahui lebih jelas laju pertumbuhan produksi padi di Kabupaten Batubara dalam kurun waktu 4 tahun terakhir 2013-2016 di Kabupaten Batu Bara per kecamatan dalam kurun waktu 4 tahun hanya Kecamatan Air Putih yang terus mengalami peningkatan produksi padi. Sementara itu, kecamatan lain mengalami fluktuasi peningkatan bahkan di Kecamatan Tanjung Tiram terus mengalami penurunan. Kondisi yang terjadi tentu banyak faktor yang menyebabkannya meskipun pemerintah Kabupaten Batubara masih menyatakan bahwa Kabupaten Batubara merupakan salah satu penyumbang padi di Sumatera Utara.

Tidak konsistennya laju peningkatan produksi padi di Kabupaten Batubara tentu banyak hal yang menyebabkannya. Untuk mencapai produktivitas padi yang tinggi bukan hal mudah, dibutuhkan berbagai faktor pendukung agar dapat berhasil. Salah satu peran pemerintah adalah memberikan subsidi untuk sektor pertanian. Subsidi adalah salah satu bentuk bantuan pemerintah untuk mengurangi beban masyarakat dengan membayar sebagian harga yang seharusnya dibayar oleh masyarakat atau kelompok masyarakat tertentu untuk memberi suatu barang atau jasa menyangkut kepentingan hidup orang banyak. Di sektor produksi padi, subsidi yang berikan pemerintah adalah subsidi pupuk. Mubyarto (2017:244) mengatakan bahwa persoalan yang selalu tidak mudah diatasi adalah persoalan keadilan. Hampir setiap kebijaksanaan jarang akan disambut dengan baik oleh semua pihak. Selalu ada saja pihak yang memperoleh manfaat lebih besar dari pihak lainnya dan bahkan ada yang dirugikan. Itulah sebabnya masalah kebijaksanaan pertanian bukanlah terletak pada banyak sedikitnya campur tangan pemerintah, tetapi berhasil tidaknya kebijaksanaan itu mencapai sasarannya dengan sekaligus mencari keadilan bagi pihak-pihak yang bersangkutan.

Selain ketersedian pupuk bersubsidi, yang menjadi harapan bagi para petani adalah harga pupuk yang murah dan terjangkau. Meskipun petani mengetahui adanya pupuk bersubsidi, namun dalam kenyataannya, tidak sedikit petani harus membeli pupuk di tingkat pengecer dengan pupuk tidak bersubsidi yang harganya lebih mahal dan terkadang pada sebagian pedagang masih melakukan upaya menaikkan harga pupuk bersubsidi dari harga yang semestinya. Penelitian ini bertujuan untuk mengetahui pengaruh ketersediaan pupuk bersubsidi dan harga yang terjangkau terhadap produksi padi di Kabupaten Batubara.

\section{METODE PENELITIAN}

Penelitian ini telah dimulai sejak Januari 2018 dan selesai pada Mei 2018. Lokasi penelitian ini dilakukan di Kabupaten Batubara yang terdiri dari 7 Kecamatan yaitu Kecamatan yaitu Sei Bilah, Kecamatan Tanjung Tiram, Kecamatan Talawi, Kecamatan Lima Puluh, Kecamatan Air Putih, Kecamatan Sei Suka dan Kecamatan Medang Deras.

Penelitian ini termasuk dalam penelitian kuantitatif. Menurut Martono (2015:215) penelitian kuantitatif merupakan penelitian yang menggunakan metode kuantitatif, yaitu sebuah metode penelitian yang bertujuan menggambarkan fenomena atau gejala sosial secara kuantitatif atau menjelaskan bagaimana fenomena atau gejala sosial yang terjadi di masyarakat saling berhubungan satu sama lain. Metode deskriptif kuantitatif dalam penelitian ini adalah metode yang digunakan dalam menyelesaikan suatu penelitian ilmiah dengan tujuan untuk memecahkan masalah yang sedang diteliti yaitu 
ketersediaan pupuk subsidi dan harga pupuk terhadap produksi padi masyarakat di Kabupaten Batubara.

Populasi adalah kumpulan dari semua kemungkinan orang-orang, benda-benda, dan ukuran lain, yang menjadi objek perhatian atau kumpulan seluruh objek yang menjadi perhatian (Suharyadi dan Purwanto, 2013:7). Dengan demikian, populasi dalam penelitian ini adalah seluruh masyarakat yang ada di Kabupaten Batubara. Berdasarkan data di BPS Kabupaten Batubara tahun 2017 diketahui bahwa jumlah penduduk dengan profesi petani adalah 67.224 jiwa/orang.

Sampel adalah suatu bagian dari populasi tertentu yang menjadi perhatian (Suharyadi dan Purwanto, 2013:7). Untuk menentukan besarnya sampel penelitian maka digunakan rumus Slovin dalam Wiratna Sujarweni (2014:16) sebagai berikut:

$$
\mathrm{n}=\frac{N}{1+N e^{2}}
$$

Keterangan

$\mathrm{n}$ : Jumlah sampel

$\mathrm{N}$ : Jumlah populasi

e : Batas toleransi kesalahan (10\%)

Berdasarkan jumlah populasi penelitian, maka yang dijadikan sampel penelitian adalah sebagai berikut:

$$
\begin{aligned}
& \mathrm{n}=\frac{67224}{1+67224(10 \%)^{2}} \\
& \mathrm{n}=\frac{67224}{1+672,24} \\
& \mathrm{n}=99,85 \\
& \mathrm{n}=100
\end{aligned}
$$

Dengan demikian, yang menjadi sampel dalam penelitian ini adalah 100 orang masyarakat yang berprofesi sebagai petani sawah di Kabupaten Batubara. Namun demikian, untuk menentukan penyebaran sampel ditetapkan berdasarkan jumlah proporsional penduduk yang berprofesi sebagai petani sawah di 7 Kecamatan di Kabupaten Baru Bara

Uji Asumsi Klasik

Dalam penelitian ini, untuk menguji hipotesis penelitian menggunakan analisis regresi linear berganda yaitu melihat pengaruh variabel bebas terhadap variabel terikat. Persyaratan dalam analisis regresi adalah uji asumsi klasik. Pengujian asumsi klasik diperlukan untuk mengetahui apakah hasil estimasi regresi yang dilakukan benar-benar bebas dari gejala tidak normalitas, adanya gejala multikolinearitas, adanya gejala heteroskedastisitas, dan gejala autokorelasi.

\section{Analisis Regresi}

Analisis Regresi Linear Berganda

Analisis regresi linier berganda adalah hubungan secara linear antara dua variabel independen yaitu ketersediaan pupuk bersubsidi $\left(X_{1}\right)$, dan harga pupuk murah $\left(X_{2}\right)$ dengan variabel dependen yaitu produksi padi (Y). Analisis ini untuk mengetahui arah hubungan antara variabel independen dengan variabel dependen apakah positif atau negatif dan untuk memprediksi nilai dari variabel depeden. 
Rumus regresi linear berganda sebagi berikut:

Keterangan:

$$
\mathbf{Y}=\mathbf{a}+\mathbf{b}_{1} \mathbf{X}_{1}+\mathbf{b}_{2} \mathbf{X}_{2}+\varepsilon
$$

$\mathrm{Y} \quad=$ Produksi padi (satuan $\mathrm{kg}$ )

a $\quad=$ Konstanta (nilai Y apabila $\mathrm{X}=0$ )

$\mathrm{b} \quad=$ Koefisien regresi (nilai peningkatan ataupun penurunan)

$\mathrm{X}_{1} \quad=$ Ketersediaan pupuk bersubsidi $/ \mathrm{kg}$ (satuan jumlah)

$\mathrm{X}_{2} \quad=$ Harga pupuk murah (satuan $\mathrm{Rp}$ )

$\varepsilon=$ Standar eror

\section{HASIL DAN PEMBAHASAN}

Analisis Deskriptif

Data hasil penelitian yang diperoleh dari responden berupa data kuantitatif, yaitu data jumlah dan jenis pupuk yang dibutuhkan untuk pertanaman padi sawah, jumlah pupuk bersubsidi yang diperoleh, harga yang dibayarkan untuk memperoleh pupuk bersubsidi, serta produksi padi sawah dalam dua musim tanam tahun 2017, yaitu musim tanam pertama (MT-1) dan musim tanam kedua (MT-2). Data yang diperoleh dari seluruh responden sebanyak 100 orang dapat diihat pada tabel 1.

Hasil penelitian menunjukkanRata-rata luas lahan sawah yang diusahakan petani adalah 0,763 Ha dengan yang paling luas 2 ha dan yang paling sempit 0,20 ha. Penanaman dilakukan 2 kali dalam satu tahun, sehingga luas panen adalah dua kali luas lahan. Total kebutuhan pupuk (urea, NPK, SP36, dan ZA) untuk pertanaman padi sawah untuk dua kali musim tanama rata-rata $897,90 \mathrm{~kg}$, paling banyak 3 ton dan paling sedikit $240 \mathrm{~kg}$. Namun demikian, dari total kebutuhan tersebut, tidak seluruhnya diperoleh dari pupuk subsidi. Rata-rata perolehan pupuk bersubsidi adalah 845,10 kg (94,56 \%) dari total kebutuhan. Tetapi bedasarkan data responden, ada petani yang memperoleh pupuk subsidi lebih dari kebutuhan (116,67 \%), tetapi ada petani yang tidak memperoleh jumlah pupuk bersubsidi sesuai dengan kebutuhan (paling rendah 69,44\%).

Harga pupuk bersubsidi untuk semua petani adalah sama, yaitu: Urea (Rp. 2000/kg), NPK (Rp. 2.500/kg), SP36 (Rp. 2.200/kg), dan ZA (Rp. 1.800/kg). Oleh karena itu, untuk analisis data harga yang digunakan adalah total harga yang harus dibayarkan petani untuk memperoleh pupuk bersubsidi, rata-rata Rp. 1.757.820,- untuk dua musim tanam, yang paling tinggi adalah Rp. 6.360.000,- dan yang paling rendah sebesar Rp. 425.000,-. Produksi gabah yang diperoleh petani dalam dua kali musim tanam rata-rata 10,288 ton, paling tinggi 28,50 ton dan paling rendah 2,50 ton. Juga dapat dilihat bahwa produksi pada musim tanam kedua lebih tinggi daripada musim tanam pertama.

Tabel 1. Analisis Deskripsi Data Responden, Tahun 2017

\begin{tabular}{clrrr}
\hline No. & Uraian & Rata-rata & Max & Min \\
\hline 1. & Luas lahan (ha) & 0,763 & 2,00 & 0,20 \\
2. & Luas panen (ha) & 1,526 & 4,00 & 0,40 \\
3. & Total kebutuhan pupuk (kg) & 897,90 & 3.000 & 240 \\
& Urea & 225,30 & 800 & 60 \\
& NPK & 232,96 & 800 & 60 \\
& SP36 & 211,80 & 600 & 40 \\
& ZA & 280,52 & 800 & 80 \\
4. & Pupuk subsidi diperoleh (kg) & 845,10 & 3.000 & 200 \\
\hline
\end{tabular}




\begin{tabular}{rlrrr}
\hline & Urea & 186,50 & 800 & 0 \\
& NPK & 152,20 & 800 & 0 \\
& SP36 & 232,00 & 600 & 50 \\
& ZA & 274,40 & 800 & 0 \\
5. & Perolehan pupuk bersubsidi (\%) & 94,56 & 116,67 & 69,44 \\
6. & Total harga pembelian (Rp) & 1.757 .820 & 6.360 .000 & 425.000 \\
7. & Produksi gabah total (ton) & 10,288 & 28,50 & 2,50 \\
& MT-1 & 4,757 & 14,00 & 1,00 \\
& MT-2 & 5,531 & 14,50 & 1,50 \\
\hline
\end{tabular}

Sumber : Data Primer (diolah), 2018

Uji normalitas dapat dilakukan dengan melihat normal probability plot yang membandingkan distribusi kumulatif dari data sesungguhnya dengan distribusi kumulatif dari distribusi normal. Untuk melihat apakah data berdistribusi normal, dilihat melalui grafik normalitas dan juga histrogram. Jika titik pada grafik mengikuti garis diagonal atau mendekatinya maka grafik tersebut menunjukkan kenormalannya, dan begitu sebaliknya. Dapat diketahui bahwa titik-titik menyebar disekitar garis dan mengikuti garis diagonal maka residual tersebut normal karena semakin dekat penyebaran titik di sekitar garis menunjukkan semakin kuat normal data. Berdasarkan grafik di atas maka dapat dinyatakan bahwa ketersediaan pupuk bersubsidi dan harga pupuk bersubsidi berdistribusi normal dengan produksi padi.

Berdasarkan bentuk histogram tersebut, terlihat jelas bahwa garis membentuk gambar lonceng dengan kedua sisi yang sama dan gambar balok lebih banyak berada dibawah garis yang membentuk lonceng. Dengan demikian, maka dapat kembali dinyatakan bahwa berdasarkan gambar histogram data variabel dinyatakan

Dari hasil di atas dapat diketahui nilai tolerance kedua variabel yaitu ketersediaan pupuk bersubsidi $\left(\mathrm{X}_{1}\right)$ dan variabel harga pupuk bersubsidi $\left(\mathrm{X}_{2}\right)$ adalah sebesar 0,993. Dengan demikian, nilai variance inflation factor (VIF) kedua variabel kurang dari 10 sehingga kedua variabel tersebut tidak ada masalah multikolinearitas.

Uji heteroskedastisitas digunakan untuk mengetahui ada atau tidaknya penyimpangan asumsi klasik heteroskedastisitas yaitu adanya ketidaksamaan varian dari residual untuk semua pengamatan pada model regresi. Prasyarat yang harus terpenuhi dalam model regresi adalah tidak adanya gejala heteroskedastisitas. Dalam penelitian ini uji heteroskedastisitas dilakukan dengan melihat pola titik-titik pada scatterplots regresi. Metode ini yaitu dengan cara melihat grafik scatterplot antara standardized predicted value (ZPRED) dengan studentized residual (SRESID). Dasar pengambilan keputusan yaitu dari output di atas dapat diketahui bahwa titik-titik tidak membentuk pola yang jelas, dan titik-titik menyebar di atas dan di bawah angka 0 pada sumbu Y. Jadi dapat disimpulkan bahwa tidak terjadi masalah heteroskedastisitas dalam model regresi.

Analisis regresi linier berganda adalah hubungan secara linear antara variabel ketersediaan pupuk bersubsidi $\left(\mathrm{X}_{1}\right)$ dan harga pupuk bersubsidi $\left(\mathrm{X}_{2}\right)$ dengan variabel produksi padi (Y).

Koefisien Determinan

Uji Determinan $\left(\mathrm{R}^{2}\right)$ dilakukan guna melihat seberapa besar pengaruh ketersedian pupuk bersubsidi $\left(\mathrm{X}_{1}\right)$ dan harga pupuk bersubsidi $\left(\mathrm{X}_{2}\right)$ dalam meningkatkan produksi padi (Y).

Angka koefisien determinasu $\left(\mathrm{R}^{2}\right)$ sebesar 0,667. Hal ini menunjukkan bahwa prosentase sumbangan pengaruh ketersedian pupuk bersubsidi $\left(\mathrm{X}_{1}\right)$ dan harga pupuk 
bersubsidi $\left(\mathrm{X}_{2}\right)$ terhadap produksi padi $(\mathrm{Y})$ sebesar $66,7 \%$. Sisanya sebesar 33,3\% merupakan faktor lain yang tidak diamati, seperti jenis bibit, serangan hama dan penyakit, pengairan, dan lain-lain. Produksi padi sangat dipengaruhi oleh kondisi lingkungan di sekitarnya, sehingga walaupun secara teknis telah dilakukan dengan baik, tetapi apabila kondisi lingkungan sekitar mengalami perubahan, maka produksi padi sawah juga akan mengalami perubahan.

Uji $\mathrm{F}$ atau simultan dilakukan untuk mengetahui apakah ketersedian pupuk bersubsidi $\left(\mathrm{X}_{1}\right)$ dan harga pupuk bersubsidi $\left(\mathrm{X}_{2}\right)$ secara bersama-sama berpengaruh terhadap produksi padi $(\mathrm{Y})$ dengan ketentuan jika $\mathrm{F}_{\text {hitung }}$ lebih besar dari $\mathrm{F}_{\text {tabel }}$ maka secara simultan (bersama-sama) ketersedian pupuk bersubsidi $\left(\mathrm{X}_{1}\right)$ dan harga pupuk bersubsidi $\left(\mathrm{X}_{2}\right)$ berpengaruh terhadap produksi padi $(\mathrm{Y})$, dan sebaliknya. Untuk mengetahui apakah $\mathrm{F}_{\text {hitung }}>$ dari $\mathrm{F}_{\text {tabel }}$ maka dapat diketahui bahwa nilai $\mathrm{F}_{\text {hitung }}$ adalah 97,130 dengan signifikansi 0,00 atau $<0,05$. Hal ini berarti terdapat pengaruh yang signifikan secara simultan (bersama-sama) dari ketersedian pupuk bersubsidi $\left(\mathrm{X}_{1}\right)$ dan harga pupuk bersubsidi $\left(\mathrm{X}_{2}\right)$ terhadap produksi padi $(\mathrm{Y})$.

Berdasarkan hasil analisis diperoleh persamaan garis regresi pengaruh ketersedian pupuk bersubsidi $\left(\mathrm{X}_{1}\right)$ dan harga pupuk bersubsidi $\left(\mathrm{X}_{2}\right)$ terhadap produksi padi (Y) sebagai berikut:

$\mathrm{Y}=11,818-0,103 \mathrm{X}_{1}+0,005 \mathrm{X}_{2}$

Interpretasi dari hasil regresi di atas adalah sebagai beriktu:

Konstanta sebesar 11,818 artinya jika variabel ketersedian pupuk bersubsidi $\left(\mathrm{X}_{1}\right)$ dan harga pupuk bersubsidi $\left(\mathrm{X}_{2}\right)$ nilainya 0 maka produksi padi $(\mathrm{Y})$ per petani di Kabupaten Batubara adalah 11,818 ton per tahun (dua musim tanam). Dengan demikian, tanpa pupuk bersubsidi juga masih akan diperoleh produksi padi, karena padi dapat tumbuh pada lahan walaupun dengan kondisi terbatas, tetapi akan berpengaruh kepada produksi yang dihasilkan.

Nilai koefisien regresi ketersedian pupuk bersubsidi $\left(\mathrm{X}_{1}\right)$ menunjukkan nilai negatif, berari bahwa ketersediaan pupuk bersubsidi pada tahun 2017 justru menyebabkan penurunan produksi padi sawah. Nilai t-hitung variabel ketersedian pupuk bersubsidi $\left(\mathrm{X}_{1}\right)$ adalah sebesar -2,156 dengan signifikansi 0,034 $(<0,05)$, yang berarti bahwa ketersediaan pupuk bersubsidi secara signifikan menurunkan produksi padi sawah pada tahun 2017. Koefisien regresi ketersedian pupuk bersubsidi $\left(\mathrm{X}_{1}\right)$ sebesar -0,103 artinya jika ketersediaan pupuk bersubsidi meningkatkan 1\%, maka akan menurunkan produksi padi sawah sebesar $103 \mathrm{~kg}$ pada dua musim tanam, dengan asumsi variabel harga pupuk bersubsidi tetap. Kondisi ini dapat dijelaskan bahwa sebagian petani ada yang memperoleh pupuk bersubsidi lebih dari yang dibutuhkan.

Nilai koefisien regresi harga pupuk bersubsidi $\left(\mathrm{X}_{2}\right)$ menunjukkan nilai positif, berari bahwa harga pupuk bersubsidi pada tahun 2017 menyebabkan peningkatan produksi padi sawah. Nilai t-hitung variabel harga pupuk bersubsidi $\left(\mathrm{X}_{2}\right)$ adalah sebesar 13,935 dengan signifikansi $0,000(<0,05)$, yang berarti bahwa harga pupuk bersubsidi secara signifikan meningkatkan produksi padi sawah pada tahun 2017. Koefisien regresi ketersedian pupuk bersubsidi $\left(\mathrm{X}_{1}\right)$ sebesar 0,005 artinya jika harga pupuk bersubsidi meningkatkan Rp. 1, maka produksi padi sawah akan meningkat sebesar $5 \mathrm{~kg}$ pada dua musim tanam, dengan asumsi variabel ketersediaan pupuk bersubsidi tetap. Hal ini menunjukkan bahwa harga pupuk bersubsidi sangat menguntungkan bagi petani.

Pupuk bersubsidi merupakan salah satu kebutuhan utama bagi para petani padi sawah untuk dapat menghasil produksi padi atau panen yang maksimal. Setiap petani sawah sangat bergantung pada kebutuhan pupuk organik yang telah diolah melalui proses kimia di berbagai pabrik pengolahan pupuk. Diketahui bahwa regulasi pupuk 
bersubsidi telah diatur sesuai dengan ketentuan yang berlaku hingga kepada petani padi sawah. Hal yang perlu ditekankan dalam penyaluran pupuk bersubsidi ini adalah petani yang berhak mendapatkan pupuk bersubsidi dari pemerintah hanyalah petani yang tergabung dalam GAPOKTAN atau Gabungan Kelompok Tani, sedangkan secara konstitusi petani yang tidak tergabung didalamnya tidak berhak mendapatkan pupuk bersubsidi.

Kebutuhan petani padi sawah terhadap pupuk bersubsidi sangat urgen sebab pada masa sekarang ini, sulit bahkan dapat hampir dipastikan tanpa pupuk maka hasil panen akan gagal. Oleh sebab itu, ketersediaan pupuk bersubsidi sangat berpengaruh terhadap produksi padi sawah. Selain ketersediaan pupuk bersubsidi tentu petani sangat berharap bahwa harga pupuk bersubsidi pada tingkat pengecer benar-benar sesuai dengan Harga Eceran Tertinggi (HET) sehingga tidak memberatkan petani.

Hasil analisis menunjukkan bahwa ketersediaan pupuk bersubsidi berpengaruh negatif terhadap produksi. Hal ini mengindikasikan bahwa penggunaan pupuk oleh petani cenderung berlebih, sehingga menurunkan efisiensi penggunaan pupuk. Hasil penelitian Bintang, Chalil dan Darus (2013) menunjukkan bahwa penggunaan faktor produksi pupuk bersubsidi di Desa Wonosari Kecamatan Tanjung Morawa Kabupaten Deli Serdang tidak efisien, karena produksi yang dihasilkan masih lebih rendah dari potensi produksi varietas padi yang ditanam petani. Hasil penelitian Asnawi, Arif dan Rohayana (2011) menjelaskan penggunaan pupuk yang berlebihan oleh petani justru berpengaruh negatif terhadap produksi padi sawah. Harga pupuk yang lebih murah dari harga pasar menyebabkan petani cenderung menggunakan pupuk berlebih.

Hasil penelitian juga menunjukkan bahwa sebagian petani memperoleh pupuk dalam jumlah yang lebih banyak dari kebutuhan, tetapi sebagian petani lainnya masih kekurangan dari jumlah yang diperlukan. Hal ini menunjukkan bahwa masih terdapat permasalahan dalam sistem penyaluran pupuk bersubsidi di Kabupaten Batubara. Selain itu juga dipengaruhi oleh tingkat pengetahuan petani terhadap penggunaan pupuk secara efisien. Petani memberikan pupuk ke lahan sawah sesuai dengan kebutuhan anjuran, atau berdasarkan perkiraan sendiri. Oleh karena itu, untuk mengetahui tingkat kesuburan lahan sawah, petani melalui kelompok tani atau penyuluh pertanian perlu melakukan kerjasama dengan lembaga penelitian atau perguruan tinggi untuk melakukan analisis kesuburan lahan sawah petani. Berdasarkan hasil analisis tersebut akan diketahui tingkat kesuburan lahan sawah petani sehingga dapat diberikan rekomendasi pemupukan yang baru, yang diharapkan dapat memberikan pengaruh yang efektif terhadap produksi padi sawah.

\section{SIMPULAN}

Berdasarkan hasil analisis dan pembahasan, maka dapat diambil kesimpulan sebagai ketersediaan dan harga pupuk bersubsidi secara simultan dan parsial berpengaruh signifikan terhadap produksi padi sawah di Kabupaten Batubara. Pengaruh variasi ketersedian dan harga pupuk bersubsidi terhadap produksi padi adalah sebesar $66,7 \%$. Ketersediaan pupuk bersubsidi secara rata-rata di Kabupaten Batubara adalah sebesar 94,56\%. Secara parsial, ketersediaan pupuk bersubsidi berpengaruh negatif terhadap produksi padi sawah di Kabupaten Batubara. Kondisi disebabkan sebagian petani ada yang memperoleh pupuk bersubsidi lebih dari yang dibutuhkan. Harga pupuk bersubsidi secara parsial berpengaruh positif terhadap produksi padi sawah, artinya bahwa harga pupuk bersubsidi masih dalam tingkat kemampuan petani.

\section{DAFTAR PUSTAKA}


Yayan Noviandi Ananda Tanjung, Yusniar Lubis \& Syaifuddin Lubis, Kajian Ketersediaan Pupuk Bersubsidi dan Harga Pupuk Terhadap Produksi Padi Sawah di Kabupaten Batubara.

Andianto, Tuhana Taufiq. 2014. Pengantar Ilmu Pertanian: Agraris, Agrobisnis, Agroindustri, dan Agroteknologi. Yogyakarta: Global Pustaka Utama.

Asnawi, Robert; Arif, Ratna Wylis; dan Rohayana, Dede. 2011. Analisis Kelangkaan Pupuk dan Pengaruhnya Terhadap Produktivitas Padi Sawah Inbrida dan Hibrida di Lampung. Balai Pengkajian Teknologi Pertanian Lampung.

Badan Pusat Statstik Kabupaten Batubara. Kabupaten Batubara Dalam Angka 2017, Limapuluh.

Balai Besar Penelitian Tanaman Padi, 2015. Pemupukan pada Tanaman Padi. Balitbangtan Kementerian Pertanian, Jakarta. http://bbpadi.litbang.pertanian.go.id/, diakses tgl. 24 Juli 2018.

Bintang, Veralina; Chalil, Diana; dan Darus, Mozart B. 2013. Analisis Efisiensi Pemakaian Pupuk Bersubsidi pada Produksi Padi Sawah (Oriza sativa L.) (Studi Kasus: Desa Wonosari, Kecamatan Tanjung Morawa, Kabupaten Deli Serdang). Program Studi Agribisnis Fakultas Pertanian Universitas Sumatera Utara, Medan.

Depdiknas. 2007. Kamus Besar Bahasa Indonesia. Jakarta: Balai Pustaka.

Dewi, I.G.A.C. 2012. Analisis Efisiensi Usahatani Padi Sawah Studi Kasus di Subak Pacung Babakan, Kecamatan Mengwi, Kabupaten Badung. Jurnal Agribisnis dan Agrowisata1(1): 1-10.

Direktorat Jenderal Prasarana dan Sarana Pertanian Direktorat Pupuk dan Pestisida. 2011. Pedoman Pembinaan Penggunaan Pestisida. Jakarta: Kementerian Pertanian.

Direktorat Jenderal Prasarana dan Sarana Pertanian. 2018. Petunjuk Pelaksanaan Penyediaan Dan Penyaluran Pupuk Bersubsidi TA 2018. Jakarta: Kementerian Pertanian.

Hanafie, Rita, 2010. Pengantar Ekonomi Pertanian. Yogyakarta: Andi.

Hasanah. Ina. 2007. Bercocok Tanam Padi. Jakarta: Azka Mulia Media.

Irawan, S. B., Siregar H., \& Kurnia U. 2006. Evaluasi Ekonomi Lahan Pertanian: Pendekatan Nilai Manfaat Multifungsi Lahan Sawah dan Lahan Kering. Jurnal Ilmu Pertanian Indonesia 11(3): 32-41.

Khomsiyatun, Nurul; Sutrisno, Joko dan Sundari, Mei Tri, 2016. Analisis Efektivitas Distribusi dan Pengaruh Pupuk Bersubsidi Terhadap Produksi Padi di Kabupaten Sukoharjo. Makalah Program Studi Agribisnis Universitas Sebelas Maret Surakarta.

Lingga, Pinus, dan Marsono. 2016. Petunjuk Penggunaan Pupuk. Jakarta: Penebar Swadaya.

Lubis, Dumalina, dkk.2011. Kajian Ketersediaan Pupuk Bersubsidi Terhadap Kebutuhan Bertanam Padi Dalam Rangka Mewujudkan Ketahanan Pangan di Kabupaten Deli Serdang. Agrica (Jurnal Agribisnis Sumatera Utara) Vol.4 No.2/Oktober 2011.

Martono, Nanang. 2011. Metode Penelitian Kuantitatif. Jakarta: RajaGrafindo Persada.

Mubyarto. 2017. Pengantar Ekonomi Pertanian. Jakarta: LP3ES.

Nizar, Rini dan Aryanto, Anto. 2013. Dampak Subsidi Pupuk Terhadap Efisiensi Usahatani padi di Provinsi Riau. Prosiding Seminar Nasional "Peranan Teknologi dan Kelembagaan Pertanian dalam Mewujudkan Pembangunan Pertanian yang Tangguh dan Berkelanjutan", November 2013. Pekanbaru.

2016. Model Fungsi Produksi Padi Pada Petani Pengguna Pupuk Subsidi di Provinsi Riau. Pekbis Jurnal, Vol.8, No.1, Maret $2016: 34-43$

Permendag No.07/M-DAG/Per/2/2009 Tentang Perubahan Atas Peraturan Menteri Perdagangan Republik Indonesia Nomor 21/M-DAG/Per/6/2008 Tentang Pengadaan Dan Penyaluran Pupuk Bersubsidi Untuk Sektor Pertanian.

Santoso, Agung Budi. 2015. Pengaruh Luas Lahan dan Pupuk Bersubsidi Terhadap Produksi Padi Nasional. Jurnal Ilmu Pertanian Indonesia (JIPI), Desember 2015 Vol. 20 (3): 208/212.

Sari, Linda Ratna dan Aslikhah, 2017. Pengaruh Subsidi Pupuk Terhadap Peningkatan Produksi dan Pendapatan Petani di Desa Sudimoro Kabupaten Jombang Dalam Perspektif Fenomenologis. Makalh pada Seminar Nasional Sistem Informasi 2017, 14 September 2017. Fakultas Teknologi Informasi UNMER Malang.

Soenandar, Meidiantie, dan Tjachjono, R. Heru. 2013. Membuat Pestisida Organik. Jakarta: AgroMedia Pustaka.

Suharyadi dan Purwanto. 2013. Statistika untuk Ekonomi dan Keuangan Modern. Jakarta: Salemba Empat.

Sujarweni, V. Wiratna. 2014. SPSS Untuk Penelitian. Yogyakarta: Pustaka Baru Press.

Suratiyah, Ken, 2015. Ilmu Usahatani. Jakarta: Penebar Sawadaya.

Syahyuti. 2007. Kebijakan Pengembangan Gabungan Kelompok Tani (GAPOKTAN) Sebagai Kelembagaan Ekonomi Di Perdesaan. Jurnal Analisis Kebijakan Pertanian (Maret) : 15-35.

Wahyu dan Setiawan, Iwan. 2017. BUMN Pangan; Evolusi Menuju Kedaulatan Pangan. Jakarta: Penebar Swadaya.

Yuliana; Ekowati, T, dan Handayani, M. 2017. Efisiensi Alokasi Penggunaan Faktor Produksi Pada Usahatani Padi di Kecamatan Wirosari Kabupaten Grobogan. AGRARIS: Journal of Agribusiness and Rural Development Research. Vol. 3 No.1 Januari 2017: 39-40 